\title{
LEGAL NATURE AND ROLE OF THE NEW STATE AGENCY FOR RESEARCH AND INNOVATION IN THE REPUBLIC OF BULGARIA
}

\author{
Zhivka Mateeva \\ Chief Assist. Prof, Ph.D., University of Economics - Varna, Bulgaria, jivkamateeva@ue-varna.bg
}

\begin{abstract}
Innovation is part of the long-term vision for the development of Bulgaria, the European Union (EU), and the world at large. Their development is a condition for increasing the competitiveness of enterprises and accelerating economic growth. Unleashing the potential of research and innovation to accelerate economic growth requires an appropriate regulatory basis and government policy to stimulate innovative activity. An important point in this regard is the establishment of the new State Agency for Research and Innovation in 2020. The current development explores the legal nature and role of the state agency as a structure that develops and implements the state policy in the field of interaction of research, innovation, and technology and the reforms related to it.
\end{abstract}

Keywords: state agency, state policy, executive administration, chairman of a state agency, powers.

\section{INTRODUCTION}

The establishment and implementation of the new common policy for the development of research, innovation, and technology in support of the economic and social development of the country is part of the reform undertaken in the research and development sector in Bulgaria. One of the main components of this reform is the establishment of a specialized unit for the implementation of the new policy and coordination of its contribution to the other national policies related to the economic and industrial transition of the country. In this regard, the new State Agency for Research and Innovation (SARI) was established at a national level. It has essential specificities such as an administrative structure of the executive established with certain tasks. The development and implementation of state policy in the field of research, innovation, and technology is a key element in enhancing the technological and economic development of our country. In this context, the role of the State Agency is essential for the implementation of a common policy for the development of research and innovation. Given the objectives of the exhibition, this development analyses the legal nature of the Agency for the implementation of state policy and synchronization with other strategic documents and policies as a guarantee of adequate public support for the research and innovation ecosystem. In conclusion, conclusions are drawn about the role and importance of the Agency, given its regulated powers, for the development of innovation activity in Bulgaria.

\section{MAIN FEATURES OF THE STATE AGENCY FOR RESEARCH AND INNOVATION}

The Law on Administration ${ }^{1}$ (LoA) governs the administration of the executive, which in legal literature is considered in a narrow and broad sense. In a narrow sense, the administration of the executive branch covers the structure, personnel, and material and technical basis, and in a broad sense - in addition to the

\footnotetext{
${ }^{1}$ Updated in State Gazette issue 130 of 5 November 1998, and amended in State Gazette issue 21 of 13 March 2020.
} 
concept in the narrow sense it also covers the executive bodies themselves (Balabanova, 2000, p. 22). In the provision of Art. 19, subparagraphs 1,2, and 3 of the Law on Administration, the legislator explicitly divides the executive branch into central and territorial. The central authorities are the Council of Ministers (CoMin), the Prime Minister, the Deputy Prime Ministers, and ministers, and the regional governors, the mayors of municipalities of districts and town halls, and the mayor's deputies are territorial. Additionally, in the provision of Art. 19, subparagraph 4 of the Law on Administration states that the presidents of the state agencies shall also be considered as executive bodies; state commissions; executive directors of executive agencies; the heads of state institutions established by law or by decree of the Council of Ministers, who have functions in connection with the implementation of the executive power. In the exercise of their powers, the executive bodies are assisted by an administration that the Bulgarian legislature divides into central and territorial, with the state agencies included in the central level (Art. 38, subparagraph 1, item 3 of the Law on Administration). The general framework of the state agencies is contained in Art. 47-49 by the Law on Administration.

Currently, 13 state agencies have been established in Bulgaria, operating within the administration of the executive branch. Almost all of them include in their name a state agency, except for the administrative structure - the National Statistical Institute, regulated by a law explicitly stated to have the status of "state agency" (Compliance review of the current model for central administration organization, January 2020, p. 61). The last administrative structure established is the State Agency for Research and Innovation.

Based on the general framework of the state agencies contained in the Law on Administration, the following main characteristics of the State Agency for Research and Innovation can be produced:

- It is an administration of direct subordination to the Ministry of Justice for the performance of activities not carried out by the Ministry. It was established by Decree No 256 of 14 September 2020 of the Council of Ministers ${ }^{2}$ as a structure to develop and implement the policy on the development of research, innovation, and technology transfer in the country. The Agency is not an executive body, but an administration created with certain tasks - it primarily develops and implements a policy for which no ministry has been established. It shall be subordinate to the Council of Ministers, which shall, within the limits of its competence under Art. 105, subparagraph. 2 of the Constitution of the Republic of Bulgaria implements the general leadership of the state administration. By decree for the establishment of the Agency, the Council of Ministers determines how the activity of the SARI works and the necessary administrative organization.

- It is a legal entity with budget support. Its Chairman is a secondary authorizing officer with a budget under the budget of the Council of Ministers, unlike other state agencies such as the State E-Government Agency, under Article $7 \mathrm{~b}(3)$ of the E-Government Act and the National Statistical Institute, under Article 6(2) of the Law on Statistics, the Presidents of which are senior authorizing officers.

- The structure, functions, tasks, staffing levels, and organization of the work of the State Agency for Research and Innovation, including the powers of its President, shall be determined by rules of procedure, the adoption of which is the exclusive competence of the Council of Ministers ${ }^{3}$. With its adoption, the Agency was entrusted with the administration of the National Innovation Fund (NIF), which is the only mechanism for supporting innovation and research and development in enterprises with funds from the state budget. NIF promotes the development of innovation by co-financing the implementation of research and development projects in enterprises under the "Support for research and development of enterprises and research and knowledge dissemination organizations" scheme ${ }^{4}$. Subsequently, by decree of the Council of Ministers, No $264 / 30.06 .2021^{5}$ the administration of the NIF went to the Ministry of Economy, with the administrator of the Bulgarian Small and Medium Enterprises Promotion Agency - (BSMEPA). The circumstances which required this change relate to the fact that the SARI is still a new structure and does not have sufficient capacity to administer it. Until the establishment of the SIRI, the NIF administration was carried out by BSMEPA, which builds on and improves its management every year. Nevertheless, SARI will play an essential role in the development and implementation of our country's common policy for the development of research, innovation, and technology. It will build on the innovation ecosystem in Bulgaria, but through its tool to complement and support innovation together with the innovative fund scheme administered by the executive agency and to support the development of research and development by science and knowledge

\footnotetext{
${ }^{2}$ Published in State Gazette issue 82 of 18 September 2020

${ }^{3}$ Rules of Procedure of the State Agency for Research and Innovation, adopted by Decree of the Council of Ministers No 70 of 02.03.2021, Promulgated in State Gazette issue 20 of 9 March 2021, as amended by State Gazette issue 27 April 2021, as amended in State Gazette issue 64 of 3 August 2021.

${ }^{4}$ Currently, the state aid regime applicable to the scheme is Commission Regulation (EU) No 651/2014 of 17 June 2014.

${ }^{5}$ Published in State Gazette issue 64 of 3 August 2021.
} 
transfer to business and society (see the report of the Minister of Economy, on amendment of Decree No 70 of 2 March 2021 on the adoption of the SARI Regulations).

- It shall be represented and chaired by a Chairperson appointed by a Decision of CoMin. In carrying out his duties, the President of the State Agency shall be assisted by vice-presidents, the number of which shall be determined in the decree establishing the SARI.

\section{STATUS AND POWERS OF THE PRESIDENT OF THE STATE AGENCY FOR RESEARCH AND INNOVATION}

The President of the SARI is the sole body of the executive. Given its powers, it is a body with special (functional) competence because it conducts its activities in a certain sphere of state government, an activity that is relevant to the whole system of executive bodies and even to the state apparatus as a whole (Lazarov, 2009, p. 41-42). It coordinates and supervises the development and implementation of the state policy of interaction between research, innovation, and technology in order to enhance the technological and economic development of Bulgaria, under Article 3(1) of the SARI Regulations of Procedure. The legislator recognizes a more special status of the President of the State Agency, which is tasked with developing and implementing a policy similar to ministers (Pehlivanov, K. 2012, p. 65).

The Chairman of the State Agency shall arise under the system of appointment. It shall be determined by the decision of the Council of Ministers and its employment contract shall be concluded, amended, and terminated by the Prime Minister. The order of broadcast predetermines the higher degree of dependence of the President of the state agency compared to the committees established by law by the constitution body (Nikolov, 2008, page 49). In this regard, it should be pointed out that the President reports to CoMin by submitting to him an annual report on the activities of the SARI and not to parliament. Moreover, the President of the State Agency is obliged to agree with the deputy prime minister concerned his decision to set up advisory councils and working groups concerning the exercise of the agency's powers and to submit annual reports on their activities.

The legislator provides for certain requirements to be met by the President of the Agency and his alternates, as such persons should carry out and comply with the common research, innovation, and technology policy, and are therefore expected to theoretical and practical training. Therefore, the President and his deputies should be Bulgarian citizens, have higher education with a minimum master's degree, with proven professional experience in the field concerned, and not be convicted of a deliberate crime of a general nature, unless they are rehabilitated. The requirement of non-conviction in the election or appointment of the President of the Agency and his alternates shall be established of its motion by the appointing authority, CoMin. While performing their duties, they may not hold any other public office; to pursue a commercial activity or to be governors, commercial proxies, sales representatives, procurators, commercial intermediaries, liquidators, or insolvency practitioners; be members of a management or control body of a non-profit legal person, commercial company or cooperative; to pursue a freelance profession, except for scientific or teaching activities or the exercise of copyright and related rights; be leaders of an election headquarters of a party, a coalition of parties or an initiative committee.

The chairman of the state agency and his deputies have all employment rights except those that contradict or are incompatible with their legal status. Termination of the legal relationship is allowed without notice in case of non-fulfillment of the obligation under Art. 36, paragraph 3 of the Counter-Corruption and Unlawfully Acquired Assets Forfeiture Act (CCUAAFA) and upon the establishment of a conflict of interest or upon the entry into force of an act establishing a conflict of interest under the CCUAAFA. The legal relations shall be terminated by the body, which appoints or determines them, at its discretion.

The powers of the President of the SARI are governed by Article 4 of the Agency's Rules of Procedure. They are related to the implementation of the state policy of interaction between research, innovation, and technology and can be grouped into the following classification groups:

\subsection{Organizational and management powers}

- Coordinates and controls government policy on synergies between research, innovation, and technology;

- Lead the development of draft regulations governing the preparation, resource provision, and implementation of the state policy, together with the other institutions relevant to its development and implementation;

- Lead the development and implementation of the Innovation Strategy for Smart Specialization and other 
strategic documents directly relevant to government policy, as well as annual and multiannual programs for their implementation;

- Lead the development and implementation activities of projects and programs financed with funds from the national budget and by international donors and other organizations that meet the objectives and priorities of the national policy and priorities of the European Union in the field of innovation and technological development and their interaction with research;

- Lead and commission the development of analyses, studies, and studies related to the analytical provision of the policy development and implementation process;

- Organize the interaction with all stakeholders and policy actors and lead programs and measures to stimulate the interaction of research with business and society;

- Guide the processes of coordination, demarcation, and complementarity between individual measures, interventions, and policy instruments;

- Lead the process of developing and implementing a communication strategy and plan to promote the national research, innovation, and technological ecosystem and conduct an information policy that ensures openness and accessibility of the agency's activities;

- Coordinate and participate in the process of assessing scientific and innovative potential, coordinate the documents for strategic planning and development of leading research and technological strands in strategic areas for technological development and investment;

- Identify, manage and implement international, national, and regional projects and programs, measures and funds to finance business-to-research interaction, innovation development, technology transfer, and product and process commercialization;

- Approve and issue internal rules, procedures, regulations, strategies, systems, as well as other acts and documents related to the organization, management, and control of the agency's activities;

- Organizes public procurement activities;

- Manages the government property provided to the agency;

- Oversee the provision of information by the Agency to the media.

\subsection{Joint Powers}

\section{$\Rightarrow$ with the Minister of Education and Science:}

- Coordinate and participate in the activities of diagnosis and mapping of the research, innovation, and technological infrastructure in the country;

- Coordinate and coordinate the process of developing and implementing policies and models to ensure the sustainability of research and innovation infrastructures, access to and use of research and innovation equipment and capacity;

- Coordinate and coordinate the country's participation in the EU framework programs for research, technological development, and innovation, maintain a national contact network, and coordinate participation in European partnerships.

\section{$\Rightarrow$ Minister of Economy and Minister of Education and Science:}

- Carry out ongoing monitoring and evaluation of the implementation and results of the policy and effectiveness of the research and innovation ecosystem.

\subsection{Control Powers}

- The President shall monitor the overall activities of the Agency, including: define its annual objectives and monitor their implementation;

- Monitor compliance with the rules on administrative services.

\subsection{Representative Powers}

- Represent the Republic of Bulgaria in fulfilling the commitments arising from international agreements 
and contracts for research, innovation, and technical cooperation, as well as in interaction with the competent authorities of the EU Member States, the EU institutions, and other international organizations.

\subsection{Powers of an Employer or Appointing Authority}

- Exercise the powers of appointing civil servants to the agency under the Civil Servants Act, as well as an employer under the Labor Code;

- Establish the organizational structure, the official timetable, and the named timetable of posts in the agency's administration.

\subsection{Other Powers}

- Support the implementation of the National Research Development Strategy;

- Supports the development of national research and innovation networks and platforms and the full participation of our country in European and international;

- Present at least once a year to the Council of States and the Smart Growth Council information on progress in the implementation of the Innovation Strategy for Smart Specialization and in the agency's policy;

- Carry out the activities of the implementation of the Classified Information Protection Act within the Agency and performs the functions of an information security officer;

- Performs other functions that are related to the activity, assigned to it by law or other legal act.

In order to carry out its activities, the President of the State Agency shall issue individual administrative acts under Art. 19, subparagraph 9 of the Law on Administration. Although the President operates an activity not carried out by the Ministry, the legislature does not provide for it to issue regulations. That decision of the legislature is maintained as correct in the doctrine, having regard to the nature of that body (Spasov, 2001, page 51). The role of the President is limited to the preparation of regulations, and responsibility for issuing them is assumed by CoMin or Minister (Pehlivanov, 2012, page 73).

An advisory board and political cabinet are set up to assist the SARI President in his work.

The Advisory Board shall consist of not less than six members who are specialists in research, innovation, and technology transfer. They shall be elected by the Chairman and shall not be remunerated for their participation in the Board. Under Art. 6, subparagraph 2 of the SARI Regulations, the Advisory Board advises and assists the President in the coordination of state policy in the field of research, innovation, and technology transfer; proposes to the President measures and actions related to the exercise of his powers in the field of research, innovation and technology transfer.

The political cabinet consists of two Vice-Presidents and a public relations expert. It shall assist the President in formulating and developing specific solutions for the definition and implementation of government policy in the field of his powers. The political cabinet has the following powers: organize and conduct the president's relations with the National Assembly, other state bodies, and non-governmental organizations and with the media by organizing meetings and interviews with representatives of the media; provide information on the President's public commitments and public appearances; organizes and conducts periodic and specialized events to familiarize itself with the results of the agency's activities.

\section{ROLE OF THE STATE AGENCY FOR RESEARCH AND INNOVATION}

SARI has a leading role in the development and implementation of our country's new common policy for the development of research, innovation, and technology. The Agency also assumes responsibility for synergies and coordination between the whole palette of national and European instruments and measures related to policy implementation. The leading strategic policy document is Innovation Strategy for Smart Specialization - (ISSS) 2021-2027, taking over functions related to its implementation and monitoring by the Ministry of Economy and being an operational unit of the Smart Growth Council ${ }^{6}$ (Program "Research, Innovation and Digitalization Program for Smart Transformation" 2021-2027, p. 21-22). In carrying out its functions, SARI interacts and coordinates its actions with the main actors in the process of developing and implementing the

\footnotetext{
${ }^{6}$ The Smart Growth Council is a permanent advisory body to the Council of Ministers, which determines the preparation and implementation of the Innovation Strategy for Smart Specialization, as well as on a new, common policy for the research development, innovations and technologies.
} 
new policy - public institutions, private entities, research organizations, innovation infrastructures, and higher education institutions.

Under Article 2, paragraph 4 of the SARI Rules of Procedure, the Agency acts as the managing authority of the Research, Innovation and Digitalization Program for Smart Transformation with all the resulting obligations and responsibilities under national and EU law. "The program meets the strategic needs and priorities of Bulgaria for the implementation of a common policy for the development of research and innovation in favor of accelerated economic development of the country. The goal is to increase the innovative performance of our country, reaching a level above $65 \%$ The EU, moving from a "modest" to a "moderate" innovator by 2030 "(Program" Research, Innovation, and Digitalization for Smart Transformation" 2021-2027, p. 2). The development and implementation of the program will be closely linked to the planning and implementation of a common policy for the development of research, innovation, and technology.

SARI has a key role to play in the development, implementation, and monitoring of ISSS 2021-2027, together with synchronization with other strategic documents and policies, such as the National Strategy for Research Development in Bulgaria 2017-2030, the National Roadmap for Scientific Infrastructure, Industry 4.0, etc. (National Plan for Reconstruction and Sustainability of the Republic of Bulgaria, July 2021, p. 72).

\section{CONCLUSION}

Based on the research done by SARI, we can summarize that its creation is an essential component of the reform undertaken in the research and development sector in Bulgaria. The main approach of this reform is the ecosystem - the construction of a sustainable research and innovation ecosystem, which allows intensive development and full contribution of all its participants. In this regard, SARI combines policy, rulemaking, and key instruments (projects and finances) as a guarantee for adequate public support of the ecosystem (National Plan for Reconstruction and Sustainability of the Republic of Bulgaria, 2021, p. 72). In general, the agency's activities allow it to play an important role in the implementation of the state policy on the interaction between research, innovation, and technology. The Agency will mainly help address the weaknesses characteristic of public institutions in terms of the lack of a strategic vision and a single innovation and research policy, as well as help to overcome the identified sectoral fragmentation.

\section{REFERENCE LIST}

Balabanova, Hr. (2000). Administratsia na izpalnitelnata vlast v zakonodatelstvoto na Republika Bulgaria. Sofia: Albatros, pp.103

Decree No 256 of 14 September 2020 of the Council of Ministers, Published in State Gazette issue 82 of 18 September 2020

Decree No 264 of 30 June 2021 of the Council of Ministers, Published in State Gazette issue 64 of 3 August 2021

Lazarov, K. (2009). Administrativno pravo. Sofia: Feneya, pp.260

Law on Administration, Updated in State Gazette issue 130 of 5 November 1998, and amended in State Gazette issue 21 of 13 March 2020

National Plan for Reconstruction and Sustainability of the Republic of Bulgaria, July 2021

Nikolov, N. (2008). Obshta harakteristika na komisiite, sazdadeni sas zakon. Savremenno pravo, (4), pp. 4159

Pehlivanov, K. (2012). Praven status na agentsiite saglasno Zakona za administratsiyata i spetsialnite normativni aktove. De Jure, (3) 1, pp. 62-73

Report of the Minister of Economy, on amendment of Decree No 70 of 2 March 2021 on the adoption of the SARI Regulations

Programme "Research, Innovation and Digitalization for Smart Transformation 2021-2027", 6674/21 ADD 1 REV 1

Rules of Procedure of the State Agency for Research and Innovation, adopted by Decree of the Council of Ministers No 70 of 02.03.2021, Promulgated in State Gazette issue 20 of 9 March 2021, as amended 
by State Gazette issue 27 April 2021, as amended in State Gazette issue 64 of 3 August 2021

Spasov, B. (2001). Izpalnitelna vlast. Sofia: Siela, pp.123

Support for public administration reform № SRSS/C2019/030, Compliance review of the current model for central administration organization, January 2020, European Commission, pp. 284 